\title{
Network Positions and the Probability of Being Acquired: An Empirical Analysis in the Biopharmaceutical Industry
}

\author{
Erica Mazzola, Giovanni Perrone and Dzidziso Samuel Kamuriwo ${ }^{1}$ \\ DICGIM - Managerial and Economics Division, Università degli Studi di Palermo, 90128, Palermo, Italy, and \\ ${ }^{1}$ Cass Business School, City University London, 106 Bunhill Row, London, EC1Y 8TZ, UK \\ Corresponding author email: giovanni.perrone@unipa.it
}

\begin{abstract}
This paper examines the relationship between the firm's direct ties, its inter-firm network prominence and its likelihood of being acquired. The authors argue that firm's direct ties and prominence enhance the firm's visibility and signal its quality - and thus foster the firm's likelihood of being acquired. However, higher levels of direct ties and prominence, by providing access to resources and the firm's status, respectively, increase the firm's ability to remain independent and thus reduce its likelihood of being acquired. Thus, the authors posit the overall relation as an inverted U-shaped. Furthermore, they show that, for firms that undergo an initial public offering, the aforementioned relation becomes much weaker. The hypotheses are empirically tested in the biopharmaceutical industry and important theoretical and managerial implications are discussed.
\end{abstract}

\section{Introduction}

In addition to Amylin, BioSeek has had collaborations with numerous pharmaceutical and biotechnology companies including Merck-Serono, UCB, and Dainippon Sumitomo. (BusinessWire, 2009)

The quote from Asterand Bioscience's announcement of its acquisition of BioSeek Inc. in 2009 is an example of the importance a target's interfirm agreement to prospective acquirers. Surprisingly, social capital (SC) literature has still not examined how a firm's network position influences its likelihood of being acquired. Past work on the impact of network positions has focused on related topics such as the firm's survival (Brüderl and Preisendörfer, 1998; Mitchell and Singh, 1996; Uzzi, 1996; Watson, 2007), the firm's dissolution (Pennings, Lee and Van Witteloostuijn, 1998) and the firm's propensity to make acquisitions or mergers (Haunschild, 1993; Hoang, 1997; Lin et al., 2009; Yang, Lin and Peng, 2011). Further, research on mergers and acquisitions (M\&A) has not used a network perspective, but, rather, has focused on dyadic relations between the target and acquirer (i.e. be they customers, suppliers or competitors). This gap is also relevant from a managerial point of view. Most firms looking for a possible buyer highlight their inter-firm relations among the 'reasons to be bought'. Furthermore, market business intelligence websites routinely provide information on the firm's inter-organizational deal activity (see for instance https://www.pharmamedtechbi.com).

In this research, we aim to fill this gap by providing possible explanations on how and why a firm's network position influences its likelihood of being acquired. We build on signaling and network theories to explain how and why the firm's direct ties and prominence in its ego network influence its likelihood of being acquired. In this paper, the focus is on inter-firm networks based on company-to-company relationships (Grandori and Soda, 1995).

We argue that the firm's direct ties and prominence are 'visibility-enhancing signals' (Pollock and Gulati, 2007) that allow the firm to 'stand-out 
from the crowd' and get noticed by potential acquisition suitors. Moreover, the firm's direct ties and network prominence signal the firm's quality, which helps to reduce the information asymmetry between the firm and the market (Ozmel, Reuer and Gulati, 2013; Stuart, 2000), thus increasing its likelihood of being acquired.

However, firms with high levels of direct ties have access to valuable resources that improve firm performance, boosting the firm's organic growth and, therefore, reducing the likelihood of its acquisition (Ahuja, 2000; Gilsing et al., 2008; Koka and Prescott, 2002; Salman and Saives, 2005; Schilling and Phelps, 2007; Soh, 2003; Vanhaverbeke, Gilsing and Duysters, 2009, 2012; Wincent et al., 2013; $\mathrm{Wu}, 2008$; Zaheer and Bell, 2005; Zaheer et al, 2010). Furthermore, a highly prominent firm signals its status, which enhances its organizational performance and thus contributes to the firm's development and independence (Ozmel, Reuer and Gulati, 2013; Podolny, 1993, 2001; Shipilov and Li, 2008).

We build on these findings from SC research to construct a theoretical framework that explains why ego firm's direct ties and network prominence have an inverted U-shaped relation to its likelihood of being acquired by a predator.

Further, we build on multiple signaling literature (Pollock and Gulati, 2007) to explain how initial public offerings (IPOs) interact with the aforementioned inverted U-shaped relations. Indeed, previous literature has largely indicated how IPOs significantly influence a firm's likelihood of being acquired (Field and Karpoff, 2002; Hovakimian and Hutton, 2010; Jain and Kini, 1999; Ragozzino and Reuer, 2007).

We test our theoretical framework on a network of inter-firm relationships of 2083 biopharmaceutical companies over the period 2001-2010. We found significant support for an inverted U-shaped relation between the firm's direct ties, network prominence and its likelihood of being acquired. For firms that have an IPO, the relation between network positions and their likelihood of being acquired is significantly weakened.

Our study contributes to the SC literature by showing mechanisms through which a firm's network position influences its likelihood of being acquired. In particular, our study highlights the connection between differences in network embeddedness and the signaling effect of visibility and quality, on the one hand, and the effect of status and resource access, on the other hand, to produce an inverted U-shaped relation between the firm's network positions and its likelihood of being acquired. Finally, we contribute to multiple signaling literature by showing the interaction between two different signals that a firm can launch: signals emanating from its network positions and from an IPO event.

In the next section, we present the theoretical framework. We then explain our methods. Finally, we discuss the results and their theoretical and managerial implications.

\section{Theory and hypotheses}

\section{The role of direct ties}

Direct ties are one of the most considered network embeddedness features in SC literature (Ahuja, 2000; Koka and Prescott, 2002; Salman and Saives, 2005; Vanhaverbeke, Gilsing and Duysters, 2012; $\mathrm{Wu}, 2008)$. We argue that firm's direct ties have a signaling and a resource access effect. As a firm's direct ties increase, the firm stands out from the crowd (e.g. Gulati and Higgins, 2003), thus increasing its likelihood of being acquired. At the same time, the firm also gains access to valuable resources through its direct ties, which allow the firm to grow (e.g. Ahuja, 2000) to a point where its strength reduces its likelihood of being acquired. Consequently, the overall impact of firm's direct ties on its likelihood of being acquired is an inverted U-shaped relation.

Building on signaling theory, an acquisition decision can be regarded as an information asymmetry problem (Bergh et al., 2014; Connelly et al., 2011; Spence, 1973, 2002). The predator - the acquiring firm - faces difficulty in assessing whether a possible prey has the quality it claims to possess. According to signaling theory, an effective signal creates a separate equilibrium between a prey that has high-quality resources versus one that does not, thus reducing or even nullifying the adverse selection problem. Connelly et al. (2011) highlight studies where signaling theory has been applied extensively to explain how young firms signal their quality to potential IPO investors through different signals, such as board characteristics (Certo, 2003; Certo, Daily and Dalton, 2001; Filatotchev and Bishop, 2002), former investments (Elitzur and Gavious, 2003; Janney and Folta, 2003, 2006), ownership (Bruton et al., 2009; Busenitz, Fiet 
and Moesel, 2005; Filatotchev and Bishop, 2002; Jain, Jayaraman and Kini, 2008) and top management quality and reputation (Coff, 2002; Cohen and Dean, 2005; Higgins and Gulati, 2006; Jain, Jayaraman and Kini, 2008; Zimmerman, 2008).

Scholars have also recognized network positions as signals (Gulati and Higgins, 2003; Nicholson, Danzon and McCullough, 2005; Ozmel, Reuer and Gulati, 2013; Stuart, 2000; Stuart, Hoang and Hybels, 1999). Stuart, Hoang and Hybels (1999) and Stuart (2000) suggest that inter-firm relationships are signals that convey social status and recognition to existing and potential customers. According to Gulati and Higgins (2003), ties to prominent actors reflect a young firm's value and mitigate the different types of uncertainty a firm faces. Nicholson, Danzon and McCullough (2005) find that biotech companies that sign interorganizational deals with pharmaceutical companies send a positive signal to prospective investors and receive substantially higher valuations. Finally, Ozmel, Reuer and Gulati (2013) show how a new venture's prominent position in networks of company-to-company relationships can signal its quality and future prospects when it is costly to form and maintain such relationships. However, in order to reduce uncertainty, signals must first attract the attention of those who use them (Pollock and Gulati, 2007). In particular, we need to focus on how a signal increases a firm's likelihood of inclusion in the 'consideration sets' (Pollock and Gulati, 2007), i.e. in the possible list of prey. As a firm's direct ties increase, it launches a visibilityenhancing signal and the firm 'stands out from the crowd' (Pollock and Gulati, 2007). Moreover, a firm's direct tie may be with a potential buyer. Previous relations are a highly significant driver of acquisitions (Balakrishnan and Koza, 1993; Gulati, 1995, 1998), since they make it possible for a firm to gather valuable information about its partner's resources, capability and reliability - thus making the information asymmetry problem less serious and, consequently, increasing the partner's likelihood of being acquired (Vanhaverbeke, Gilsing and Duysters, 2002).

At the same time, firm's direct ties signal its resource quality, higher reputation and trustworthiness. A firm with more direct ties is, indeed, probably sought after by other firms because of its valuable resources, such as knowledge, technology, patents and products that it can share with its partners (Holcomb and Hitt, 2007; Inkpen,
1998; Mowery, Oxley and Silverman, 1996; Zhang, Baden-Fuller and Mangematin, 2007). Furthermore, a firm's level of direct ties also reflects its capability to deal with inter-firm relationships (Anand and Khanna, 2000; Barkema and Vermeulen, 1998; Hagedoorn and Duysters, 2002; Kale and Singh, 200; Villalonga and McGahan, 20057; Wang and Zajac, 2007) signaling in this way its reputation and trustworthiness (Dyer and Singh, 1998; Gulati, 1995; Gulati, Nohria and Zaheer, 2000; Hagedoorn, Roijakkers and Kranenburg, 2006; Parkhe, 1993; Ring and Van de Ven, 1992). Thus, direct ties act as a 'prism' that reflects information cues about the quality of the firm (Podolny, 2001; Soh, Mahmood and Mitchell, 2004) reducing the information asymmetry between itself and the market - and thus increasing its likelihood of being acquired.

Summarizing, the signaling effect of direct ties increases the visibility of the firm. The firm's visibility also becomes a signal of its quality, and the probability of its acquisition further increases.

Nevertheless, at high levels of direct ties, the resource effect becomes relatively more significant than the signaling effect. Firms with relatively higher direct ties have greater direct access to valuable resources such as information (Ahuja, 2000; Gulati, 1999), capabilities and learning (Powell, Koput and Smith-Doerr, 1996) and assets such as knowledge, technology, patents and services (Holcomb and Hitt, 2007; Inkpen, 1998; Mowery, Oxley and Silverman, 1996; Zhang, Baden-Fuller and Mangematin, 2007). For instance, Gulati (1999) highlights the concept of network resources, i.e. how firms derive resource benefits from their network positions.

A firm with many direct ties is likely to develop the necessary internal capabilities to absorb, internalize or exploit external resources (Anand and Khanna, 2000; Barkema and Vermeulen, 1998; Hagedoorn and Duysters, 2002; Kale and Singh, 2007; Villalonga and McGahan, 2005; Wang and Zajac, 2007). From the seminal work of Uzzi (1996), subsequent network-based scholars have focused on evaluating the impact of direct ties on the firm's economic-financial performance (Baum, Calabrese Silverman, 2000; Koka and Prescott, 2002; Wu, 2008) and innovation performance (Ahuja, 2000; Mazzola, Perrone and Kamuriwo, 2015; Salman and Saives, 2005; Vanhaverbeke, Gilsing and Duysters, 2012). For example, Salman and Saives (2005) found that, by occupying a direct 
central network position, a firm is more likely to access useful knowledge from its direct partners and increase its innovation performance. Further, the rate of performance improvement enjoyed by the firm is higher when the firm accesses a greater number of external resources through is direct ties. We argue that such performance improvement allows the firm to keep its independence either by resisting acquisition or by simply not becoming a soft takeover target.

Moreover, the signaling effect of direct ties is subject to diminishing returns (Cohen and Dean, 2005). In other words, at higher levels of direct ties, additional direct ties would have less signaling impact. At higher levels of direct ties, the signaling effect is marginally less important, while the resource effect is relatively stronger because of the number of direct ties the firm can count on. Thus, for higher levels of direct ties in its ego network, the likelihood that the firm will be acquired is significantly lower.

Summarizing, we formulate the following hypothesis:

H1: The firm's direct ties in its inter-firm network have an inverted U-shaped relationship to the likelihood of being acquired.

\section{The role of network prominence}

A firm has a prominent position in its ego network when it is either directly tied to many other firms or connected to firms who are themselves linked to many actors (Koka and Prescott, 2008). Similarly to our argument above, moderate levels of prominence (i.e. direct and indirect ties) increase the firm's visibility and quality signals, thereby increasing the likelihood that the firm will be acquired. However, stronger levels of prominence denote the firm's status, a condition that has been associated with superior performance (Jensen, 2003; Ozmel, Reuer and Gulati, 2013; Shipilov and $\mathrm{Li}, 2008$ ) and would consequently lower the firm's likelihood of being acquired. Hence, the overall impact of a firm's network prominence on the probability that it would be acquired is an inverted U-shaped relation.

A firm's prominence is a visibility-enhancing signal gained either through the ego's direct links or through the connections of highly prominent firms with whom the ego is connected. The firm's signaling also works indirectly through firms con- nected with the ego that are themselves highly connected and are considered reliable and trustworthy sources of information. Prominence is a signal of unobservable quality (Jensen, 2003) especially for firms that are indirectly tied to the focal firm and cannot directly observe the quality of the target firm. Information asymmetry between a potential acquirer and a prominent target firm is reduced, thus increasing the target firm's likelihood of being acquired. Visibility and quality signals derived from a target firm's prominence are not restricted to direct ties. Thanks to indirect ties, the signaling effects derive from the furthest tentacles of the firm's ego network (Jensen, 2003; Ozmel, Reuer and Gulati, 2013; Stuart, Hoang and Hybels, 1999) something which past M\&A studies, based on dyadic relations, have not been able to assess.

Stronger levels of prominence have been associated with status (Benjamin and Podolny, 1999; Podolny, 2001), a network condition in which the firm expresses its power (Bonacich, 1987), influence and legitimacy (Koka and Prescott, 2008) and prestige (Ozmel, Reuer and Gulati, 2013; Shipilov and $\mathrm{Li}, 2008)$.

A high-status firm can improve its performance through at least three mechanisms. First, the firm is in a better position to attract financial resources, from investors and banks, to finance its developing programs (Rao et al., 2000). Second, having a superior standing in the industry, the firm commands premium prices as it leverages its reputation to consumers and other actors for commensurate returns (Podolny, 1993; Shipilov and Li, 2008). Finally, when a high-status firm ties up with a lowstatus one, it can ask for compensation as a price for its cooperation, acquiring in this way valuable resources at a reduced price.

Furthermore, thanks to the 'homophily' mechanism (McPherson, Smith-Lovin and Cook, 2001), a superior status allows the firm to obtain advantageous positions in resource exchanges with other firms. Such a condition reduces firm's acquisition probabilities. Indeed, especially when transaction uncertainty is relevant, firms tend to collaborate with firms that have similar status. This behavior reduces the risk of opportunism, because fairness and commitment are more likely to happen among partners with similar status (Chung, Singh and Lee, 2000). However, by tying with a lower-status partner, a high-status firm risks adversely affecting its own status in the considerations of similar 
status partners. Thus, a high-status firm is likely to have inter-organizational relations with other high-status firms that are more likely have valuable resources to exchange. Finally, firms may use their high status to lock-in customers to their products, reducing competitive pressure and in this way increasing their revenues (Shipilov and Li, 2008).

Summarizing, rising levels of network prominence allow the firm to enhance its visibility and quality signals, thus increasing the likelihood of its acquisition. However, as the firm becomes highly prominent, its signaling effect is less relevant, owing to the diminishing returns effect; thus, the status effect dominates and increases the chance of the firm's independence by contemporarily reducing the likelihood of its own acquisition. Hence, we formulate the following hypothesis:

H2: The firm's prominence in its inter-firm network has an inverted U-shaped relationship to the likelihood of being acquired.

\section{The role of an IPO event}

An IPO is a significant signaling and resource mobilization method that has been highlighted in the management and entrepreneurship literature, and it may therefore influence the firm's likelihood of being subsequently acquired. Thus, it is relevant to explore how IPOs may interact with a firm's network positioning in determining its likelihood of being acquired.

A wide stream of literature considers IPOs and takeovers as strictly related to each other. An IPO has been considered as a signal that a firm launches as the first stage of an acquisition process (e.g. Field, 1999; Jain and Kini, 1999). According to this argument, firms issue IPOs to obtain a market value of their assets - which facilitates the sale of the firm - either gradually through a reduction in ownership or immediately through a subsequent acquisition. Thus, an IPO works as a signal to prove the firm's value and the quality of the firm's resources through a market evaluation, therefore increasing the firm's likelihood of being acquired (Brennan and Franks, 1997).

However, through an IPO, a firm acquires the necessary resources to develop its growth strategies, and thus it increases the firm's capacity to resist any future attempts at being taken over through acquisitions. Moreover, IPO firms can take advantage of the cash raised in the IPO, subsequent access to public financing and the ability to fund any future acquisitions with publicly traded stock to strengthen its position, and hence reduce any likelihood of being acquired (Field, 1999; Hovakimian and Hutton, 2010).

In Hypothesis 1 and Hypothesis 2, we argue that moderate levels of direct ties and network prominence acting, respectively, as visibility-enhancing and quality signals, push the firm's acquisition; but higher levels of direct ties and prominence, by providing, respectively, access to resources and firm's status, reduce acquisition probabilities. However, what is the effect on Hypothesis 1 and Hypothesis 2 when the firm has undergone an IPO?

We argue that, relative to the firm's network positions such as direct ties and prominence, an IPO is a stronger visibility-enhancing signal for the firm (Pollock and Gulati, 2007). Indeed, firms that undergo an IPO become well known to the financial, economic and institutional operators. Also, IPO firms are highly visible within the industry. An IPO is also a signal of the quality of the firm's products (Stoughton, Wong and Zechner, 2001) and its potential sales and earnings before interest, taxes, depreciation and amortization (Zheng and Stangeland, 2007). Thus, we can argue that going through an IPO is such a strong visibility and quality signal that it completely subsumes the visibility and quality-signaling role of the firm's network positioning. Therefore, the signaling impact of direct ties and prominence for IPO firms is less relevant, or even irrelevant, than for non IPO-firms. Furthermore, because an IPO indubitably provides the firm with resources and status, the likelihood of its acquisition reduces. Indeed, through an IPO, the firm obtains the necessary amount of cash to develop its growth programs. Such resources are even more significant considering that the firm can use its financial strength to access further financial resources or to use publicly traded stock to acquire some other external assets. Thus, the amount of resources obtained through an IPO makes the firm stronger and therefore less vulnerable to acquisition predators.

Finally, much of the IPO research includes a discussion on the role of the IPO and the firm's status for several reasons (Field, 1999; Field and Karpoff, 2002; Hovakimian and Hutton, 2010; Pollock and Gulati, 2007). First, an IPO firm is included in public lists of funded companies; this allows the IPO firm to be differentiated from other companies and to access, via a 'homophily' 
mechanism, value from associating with firms having the same status. Second, the firm gets access to financial and institutional partners who may help the firm to reinforce its reputation. Third, by going public, the firm can attract to its board prestigious directors who may significantly contribute to the prestige and reputation of the firm. Finally, public firms are usually subject to relatively more stringent monitoring and control by authorities, and this reinforces the reliability and trustworthiness of the firm itself. The status obtained through an IPO allows the firm to develop takeover defense strategies (Field and Karpoff, 2002). To conclude, by overshadowing the signaling effect of direct ties and prominence while additionally providing resources and status that allow the firm to defend itself from takeovers, an IPO may reduce or even nullify the effect of direct ties and network prominence on the likelihood of being acquired.

However, this negative moderating effect is not symmetric. Indeed, once a firm has an IPO, how is it differentiated from other IPO firms? Network features can help in this case by providing a complementary signal (Gulati and Higgins, 2003). In the case of IPO firms, since they are already visible, further differentiation among IPO firms would involve stronger signals from the network, i.e. a high level of direct ties and network prominence. A high level of direct ties may place IPO firm in connection with possible acquirers, increasing the probability to be included in a list of companies to buy. Furthermore, a highly prominent IPO firm is differentiated from the others, providing a 'network status' alongside the 'IPO status'. Thus, strong values of direct ties and prominence, by providing complementary signals to an IPO firm, allow it to be differentiated from the other IPO firms and attenuate the negative effect of the network features on the likelihood of being acquired. Summarizing the above reasoning, we hypothesize:

H3: The curvilinear (inverted U-shaped) relationship between the firm's direct ties and prominence and the likelihood of being acquired is weaker if the firm undergoes an IPO. However, for high values of direct ties/prominence, the negative moderation effect of the IPO is attenuated.

Figure 1 graphically represents the moderator's effect of IPO on the relation between the firm's direct ties/prominence and the probability of being acquired. Thus, following the considerations stated in Hypothesis 3, an IPO produces an inverted U-shaped relationship nested within (i.e. vertically under) the relationship (the dotted line in Figure 1) for the non-IPO case (the continuous line in Figure 1). However, as depicted in Figure 1, for strong values of direct ties/prominence, this negative moderator effect is attenuated, as strong direct ties and prominent positions allow differentiation among IPO firms, contributing to signaling them for possible acquisitions.

\section{Research method}

\section{Sample and data}

We empirically test the hypotheses in the biopharmaceutical industry. Indeed, with the advent of biotechnologies, pharmaceutical companies have lagged on research productivity (Bradfield and El-Sayed, 2009; DiMasi, Hansen and Grabowski, 2003; Goozner, 2004; Rockoff, 2015). For a pharmaceutical company, transitioning to new biotechnology research frameworks means a loss of between $80 \%$ and $100 \%$ prior knowledge (Rothaermel, 2001). Thus, these companies have been acquiring the necessary knowledge and intermediate products (patents, technologies, skills) from biotech firms through alliances and acquisitions (Al-Laham, Amburgey and Bates, 2008; Powell, Koput and Smith-Doerr, 1996).

Small biotechnology firms have promising novel intellectual property. However, their dream of becoming a vertically integrated 'pharma-like' company slams against their inability to conduct capital-intensive downstream value chain activities such as conducting clinical trials, managing the regulatory approval process and finally commercializing the product. Thus, many new biopharmaceutical firms are actually founded with the specific intent of generating early-stage drug discovery and development and then being sold, sooner or later, to large corporations (Arora and Gambardella, 1990). Thus, in recent decades, researchers have observed a large number of acquisitions in the biopharmaceutical industry (Danzon, Epstein and Nicholson, 2007; Higgins and Rodriguez, 2006). This trend is not yet exhausted - a recent IMAP report indicates that, for 2013, there were 615 announced and/or closed 


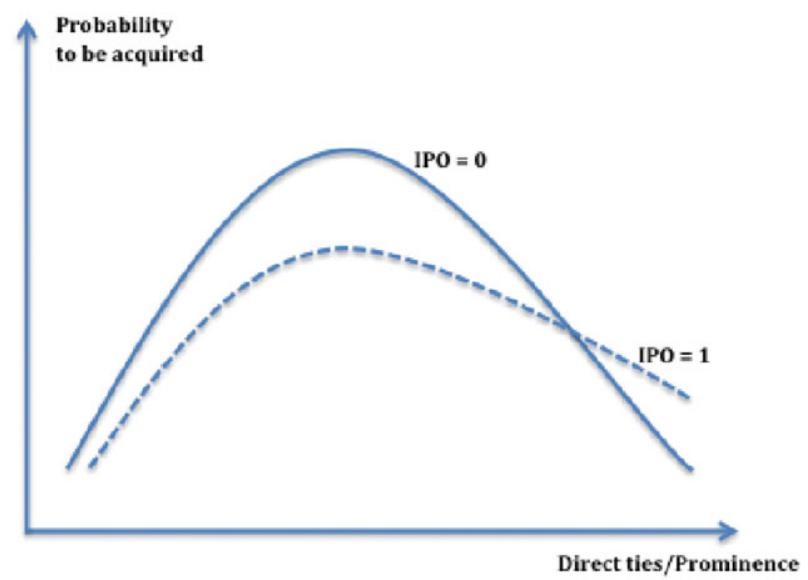

Figure 1. The Effect of IPO on the relationship between direct ties/prominence and firm's acquisition

transactions, worth US $\$ 100$ billion - an increase of $34 \%$ with respect to 2012 (IMAP, 2014).

Our investigation is based on secondary data collected from the BioWorld database, an online information service providing daily news and analysis, stock indices, company coverage, regulatory and patent reports, and other information in the biopharmaceutical industry (Al-Laham, Amburgey and Bates, 2008; Birch, 2008). We collected data about any possible biopharmaceutical company in the data set from the years 2001-2010. We have excluded from our data set those firms that either went out of business or went through a partial acquisition during the period of observation. Thus, our final data set consists of 2083 firms, of which 441 (21\%) were completely acquired in the observed period 2001-2010, while the rest were still independent.

\section{Variable definitions and operationalization}

Dependent and independent variables. The dependent variable, $A c q_{i}$, is a dummy variable, taking the value of 1 if the firm $i$ was acquired in the period 2001-2010, 0 otherwise.

As for our explanatory variables, we built the network of inter-firm agreements of the biopharmaceutical firms for each year $t$ from 2001 to 2010. Inter-firm agreements consist of any kind of inter-organizational relationships (unilateral contracts, bilateral alliances, minor equity alliances, joint ventures, M\&A) recorded and collected from the BioWorld database. We constructed, for each year, a network represented by a square matrix
$\mathbf{A}^{\mathbf{t}}\left(n^{t} \times n^{t}\right)$, where $n^{t}$ is the number of firms involved in the inter-firm agreements in the year $t$. The generic element of the matrix $\mathbf{A}^{\mathbf{t}}, a_{i j}{ }^{t}$, is equal to 1 , if firms $i$ and $j$ are involved in an agreement in the year $t, 0$ otherwise.

The degree centrality measure captures the number of direct ties connected to the ego firm, and it is the most common measure of direct ties centrality in SC literature (Ahuja, 2000; Koka and Prescott, 2002; Salman and Saives, 2005; Vanhaverbeke, Gilsing and Duysters, 2012; Wu, 2008). Thus, as a measure of direct ties centrality of a firm $I$, we calculated the average degree, $D g r_{i}$, of the firm $i$ in the years before the acquisition, if the firm has been acquired, or in 2010, in cases the firm remains independent. Thus, this variable is computed as $D g r_{i}=\frac{\sum_{t=2001}^{T} D g r_{i}^{t}}{T-2000}$, where $D g r_{i}{ }^{t}$ is the number of different ties (agreements) the firm $i$ has at time $t$, and $T$ is the year before the acquisition of $i$ if the firm has been acquired, or is equal to 2010 if the firm remains independent.

In order to take account of the prominence of the firm in its ego-network, we employed the eigenvector centrality measure (Ahuja, 2000; Al-Laham, Amburgey and Bates, 2008; Bonacich, 1987; Koka and Prescott, 2002). Eigenvector centrality refers to the extent to which the firm's centrality depends on the centrality of the firms to which it is tied. Hence, a firm has a high value of eigenvector centrality if it is connected to many actors who are themselves connected to many actors. The eigenvector centrality measure has been commonly associated with a firm's prominence by several SC scholars (Koka and Prescott, 2008; Ozmel, 
Reuer and Gulati, 2013; Shipilov and Li, 2008). To evaluate the eigenvector centrality of a firm at time $t$, Eig $_{i}{ }^{t}$, we used the 'Eigenvector' routine implemented in UCINET VI (Borgatti, Everett and Freeman, 2002) applied at the year $t$ matrix $\mathbf{A}^{\mathbf{t}}$. Again, we computed the average eigenvector centrality, $\operatorname{Eig}_{i}$, as the average of $\operatorname{Eig}_{i}{ }^{t}$ at the year before the acquisition if the firm has been acquired, or at the year 2010, in the case where it has not been acquired, i.e. $\operatorname{Eig}_{i}=\frac{\sum_{t=2001}^{T} \mathrm{Eig}_{i}^{t}}{T-2000}, T$ being the year before the acquisition (if the firm is acquired) or 2010 if not. Because of the high dispersion of this variable, we computed the natural logarithm of $\mathrm{Eig}_{i}$, so our actual independent variable is LnEig $_{i}$.

Control variables. We included many other factors that may influence the likelihood that a biopharmaceutical firm will be acquired. First, we controlled for the Age of the firm at the year before its acquisition or at 2010 (if not acquired). The firm's age is an important determinant of the firm's survival probability, because older firms have greater market experience, and they are less likely to be acquired (Evans, 1987; Pennings, Lee and Van Witteloostuijn, 1998). Second, we controlled for the nationality of the firm. Our data set consists of both US biopharmaceutical firms $(57.7 \%)$ and non-US firms $(42.3 \%)$. The American biopharmaceutical industry is the most globally developed (Danzon, Epstein and Nicholson, 2007; Higgins and Rodriguez, 2006) and so we expect USA biopharmaceutical companies to have a greater chance of being acquired. Thus, we included the variable nationality (Nat) as a dummy, taking value 1 if the firm is an American one, 0 otherwise. Third, the number of products launched by the firm can also influence the likelihood of its acquisition. Indeed, a product is a signal that the firm has successfully integrated the downstream value chain with the abilities needed to develop new drugs (Billitteri, Lo Nigro and Perrone, 2013). Furthermore, biopharmaceutical firms with launched products are more likely to have products under development in their pipeline, and therefore represent a possible target for pharmaceutical firms, in need of filling their own product pipeline (Danzon, Epstein and Nicholson, 2007; Higgins and Rodriguez, 2006). Thus, we included a count measure of new products launched by each firm from 2001 until the year before the acquisition or at 2010 (if the firm remains independent). This information was retrieved from the product section of
Table 1. Firm size categories and intervals

Size categories Employee intervals

Micro-firms (MI)

Very small firms (VS)

Small firms (SM)

Medium firms (ME)

Large firms (LA)

Very large firms (VL)

Corporation (CO)

Large corporation (LC)

$1-10$

$11-50$

51-200

201-500

$501-1000$

$1001-5000$

5000-10,000

$>10,000$

BioWorld. We included the logarithm of the number of products, LnProd, as the control variable. Fourth, the number of previous collaborations is one of the most significant drivers of acquisitions (Gulati, 1995, 1998; Hagedoorn, Roijakkers and Kranenburg, 2006). Thus, we also controlled for the number of previous collaborations (PrevColl) that the acquired firm had with the acquiring firm. Fifth, we also controlled for the Size of the firm. Larger firms are less likely to be acquired because of the inhibitive financial resources needed and the potentially high level of risk involved. We measured the size of each company by the number its employees (Powell, 1997). Since we dealt with both public and private companies, it was not easy to find out the exact number of employees of all the firms. Thus, we collected employees' data in the year of the firm's acquisition or at 2010, if not acquired, using a categorical variable according to the intervals reported in Table 1. Size data was collected from K10-reports for public firms and from several other web resources, such as LinkedIn, for other firms.

Sixth, IPOs may also influence the probability of a firm's being acquired. We operationalized $I P O$ as a variable equal to 1 where the firm went through an IPO before the acquisition or up to 2010, 0 otherwise. We gathered this information from the IPO section of the BioWorld database. We can expect a positive or negative impact of this variable, respectively, depending on whether the IPO works as a signal (Brennan and Franks, 1997; Field, 1999; Jain and Kini, 1999) or mainly as a source of resources needed to resist possible acquisitions (Field, 1999; Field and Karpoff, 2002; Hovakimian and Hutton, 2010).

We also controlled for the number of patents and its square. Indeed, literature is quite unanimous in considering patents as a signal of quality for technology firms (Baum and Silverman, 2004; Hsu and Ziedonis, 2008, 2013). Patents 
Yearly acquisition

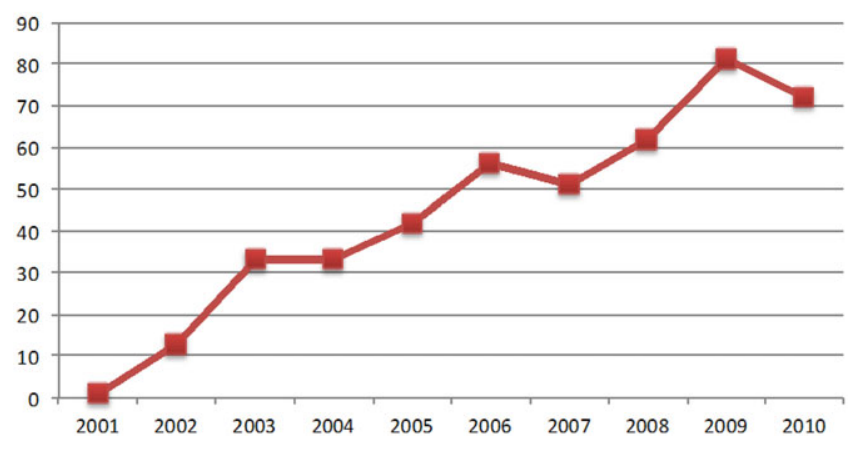

Figure 2. Number of acquisitions in the observed period (2001-2010)

represent valuable assets that other firms may be interested in capturing through an acquisition (Ali-Yrkkö, Hyytinen and Pajarinen, 2005). Thus, patents are positively related to acquisition probabilities (Long, 2002). However, patents may also be a source of revenue that may contribute to the growth of young start-ups (Helmers and Rogers, 2011). Especially in high-tech industries, many firms engage in producing and selling patents to the downstream knowledge value chain (Lerner, 1995; Mazzola, Bruccoleri and Perrone, 2015; Pisano, 1990; Powell and Brantley, 1992; Powell, Koput and Smith-Doerr, 1996) obtaining a level of cash needed to resist to possible acquisitions (Wagner and Cockburn, 2010). Therefore, patents may have an inverted U-shaped impact on the likelihood of being acquired. We collected the number of patents developed by the firm from 2001 to the year before its acquisition or at 2010 (if not acquired) from the United State Patent and Trademark Office (USPTO) database. Because of the high dispersion of this variable, we used the natural logarithm of the patent number, LnPat, and its square, LnPatSqr.

Finally, we attempted to control for the year of acquisition in order to check for possible influence of acquisition trends in some particular years. However, controlling for the years introduces a perfect collinearity with the dependent variable just because each year variable would predict a perfect success (a value of 1) of the dependent variable. Thus, we analyzed year-specific behaviors in order to locate whether some years could introduce some singularity into our data. Figure 2 shows how acquisitions in the observed years (2001-2010) present a clear growing trend, but no years seem to explain acquisitions better than others.

\section{Findings}

Table 2 provides the descriptive statistics and the correlations between all the variables. All the correlation coefficients between the independent variables are quite low. To assess the potential threat of collinearity, we estimated the variance inflation factors (VIFs) and found that no variable had a VIF greater than 2.56, which is below the recommended ceiling of 10 (Stevens, 1992).

Since the dependent variable is dichotomous, we can run a probit or logit regression (Hoetker, 2007). The choice between logit and probit models is largely one of convenience and convention, since both the models tend to produce very similar predictions, and the results are generally indistinguishable (Long, 1997). In this paper, we used a probit estimation. Table 3 provides an overview of the results.

The baseline model (model 1) shows the effects of control variables. Models 2 and 3 test for the main effect $(D g r)$ and squared effect $(D g r S q r)$ of the degree centrality, respectively. The main effect of eigenvector centrality (LnEig) is reported in model 4, while its square effect is reported in model 5 (LnEigSqr). Model 6 puts together the variables under investigation, $D g r$ and LnEig and their squared terms. Model 7 tests the interactions between $D g r$ and IPO, and between $D g r S q r$ and $I P O$, while model 8 tests the interaction between LnEig and IPO, and the interaction between LnEigSqr and IPO. The model fitting increases each time the explanatory variables, both plain and squared, and the interaction terms are introduced. All the control variables, except LnProd, are significant (model 1). The coefficient of Age is negative, and thus, as expected, older firms are less 


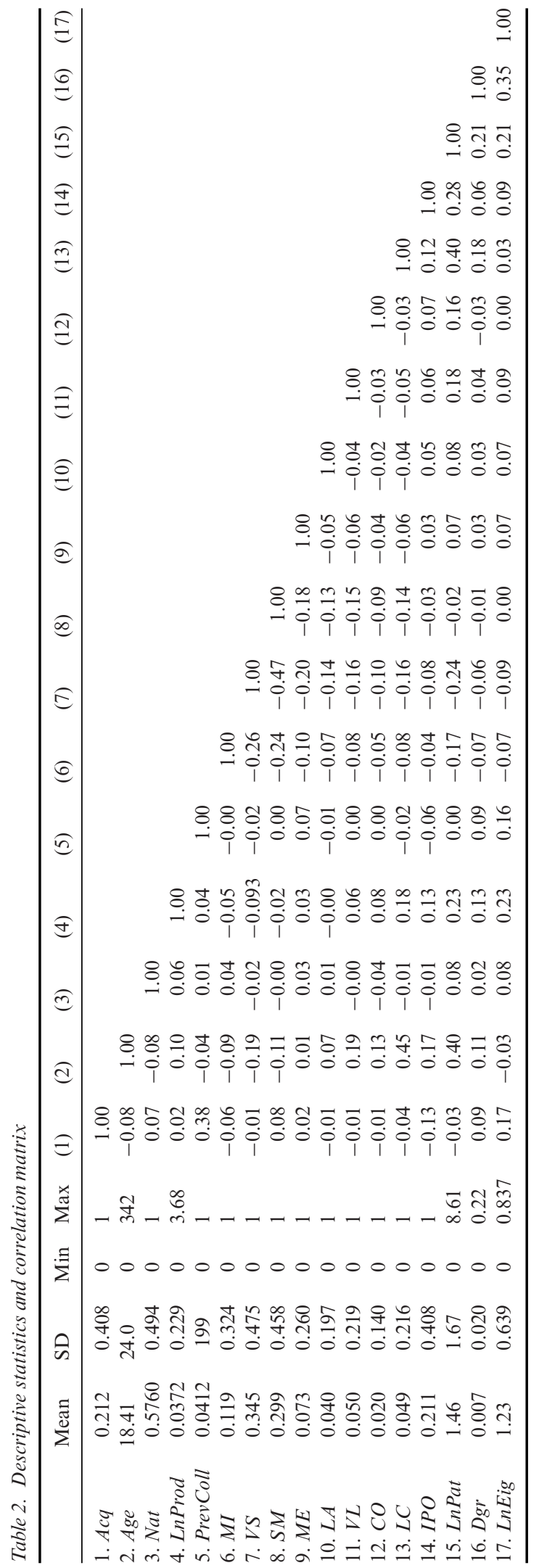


Table 3. Results of the probit analysis

\begin{tabular}{|c|c|c|c|c|c|c|c|c|}
\hline & \multicolumn{8}{|c|}{ Probability of being acquired - Probit models } \\
\hline & M1 & $M 2$ & M3 & M4 & M5 & M6 & $M 7$ & M8 \\
\hline Age & $\begin{array}{r}-0.00477^{\dagger} \\
(0.00252)\end{array}$ & $\begin{array}{r}-0.00388 \\
(0.00241)\end{array}$ & $\begin{array}{r}-0.00415^{\dagger} \\
(0.00245)\end{array}$ & $\begin{array}{r}-0.00471^{\dagger} \\
(0.00251)\end{array}$ & $\begin{array}{r}-0.00430^{\dagger} \\
(0.00245)\end{array}$ & $\begin{array}{r}-0.00379 \\
(0.00239)\end{array}$ & $\begin{array}{r}-0.00444^{\dagger} \\
(0.00248)\end{array}$ & $\begin{array}{r}-0.00447^{\dagger} \\
(0.00250)\end{array}$ \\
\hline Nat & $\begin{array}{c}0.221 * * \\
(0.0692)\end{array}$ & $\begin{array}{c}0.202^{* *} \\
(0.0698)\end{array}$ & $\begin{array}{c}0.201 * * \\
(0.0700)\end{array}$ & $\begin{array}{c}0.217 * * \\
(0.0694)\end{array}$ & $\begin{array}{c}0.203 * * \\
(0.0697)\end{array}$ & $\begin{array}{c}0.189 * * \\
(0.0702)\end{array}$ & $\begin{array}{c}0.202^{* *} \\
(0.0699)\end{array}$ & $\begin{array}{c}0.200^{* *} \\
(0.0698)\end{array}$ \\
\hline LnProd & $\begin{array}{c}0.235 \\
(0.148)\end{array}$ & $\begin{array}{c}0.0971 \\
(0.165)\end{array}$ & $\begin{array}{c}0.163 \\
(0.149)\end{array}$ & $\begin{array}{c}0.220 \\
(0.152)\end{array}$ & $\begin{array}{c}0.247^{\dagger} \\
(0.141)\end{array}$ & $\begin{array}{c}0.185 \\
(0.147)\end{array}$ & $\begin{array}{c}0.179 \\
(0.155)\end{array}$ & $\begin{array}{c}0.238 \\
(0.148)\end{array}$ \\
\hline PrevColl & $\begin{array}{l}2.967 * * * \\
(0.289)\end{array}$ & $\begin{array}{l}2.894 \text { *** } \\
(0.289)\end{array}$ & $\begin{array}{l}2.918^{* * * *} \\
(0.296)\end{array}$ & $\begin{array}{l}2.914 \text { *** } \\
(0.292)\end{array}$ & $\begin{array}{l}2.967 * * * \\
(0.333)\end{array}$ & $\begin{array}{l}2.930 \text { *** } \\
(0.328)\end{array}$ & $\begin{array}{l}2.931 * * * \\
(0.300)\end{array}$ & $\begin{array}{l}2.954 * * * \\
(0.295)\end{array}$ \\
\hline$V S$ & $\begin{array}{c}0.305^{*} \\
(0.123)\end{array}$ & $\begin{array}{c}0.285^{*} \\
(0.123)\end{array}$ & $\begin{array}{c}0.284^{*} \\
(0.124)\end{array}$ & $\begin{array}{c}0.294^{*} \\
(0.123)\end{array}$ & $\begin{array}{c}0.272^{*} \\
(0.124)\end{array}$ & $\begin{array}{c}0.263^{*} \\
(0.124)\end{array}$ & $\begin{array}{c}0.284 * \\
(0.124)\end{array}$ & $\begin{array}{c}0.261^{*} \\
(0.124)\end{array}$ \\
\hline$S M$ & $\begin{array}{l}0.510^{* * * *} \\
(0.125)\end{array}$ & $\begin{array}{l}0.474^{* * * *} \\
(0.125)\end{array}$ & $\begin{array}{l}0.466^{* * * *} \\
(0.126)\end{array}$ & $\begin{array}{l}0.501^{* * *} \\
(0.125)\end{array}$ & $\begin{array}{l}0.473^{* * *} \\
(0.126)\end{array}$ & $\begin{array}{l}0.444^{* * * *} \\
(0.126)\end{array}$ & $\begin{array}{l}0.462^{* * * *} \\
(0.126)\end{array}$ & $\begin{array}{l}0.460^{* * *} \\
(0.126)\end{array}$ \\
\hline$M E$ & $\begin{array}{r}0.286^{\dagger} \\
(0.174)\end{array}$ & $\begin{array}{c}0.236 \\
(0.175)\end{array}$ & $\begin{array}{c}0.230 \\
(0.175)\end{array}$ & $\begin{array}{c}0.276 \\
(0.175)\end{array}$ & $\begin{array}{c}0.242 \\
(0.177)\end{array}$ & $\begin{array}{c}0.206 \\
(0.177)\end{array}$ & $\begin{array}{c}0.222 \\
(0.175)\end{array}$ & $\begin{array}{c}0.246 \\
(0.175)\end{array}$ \\
\hline$L A$ & $\begin{array}{r}0.378^{\dagger} \\
(0.206)\end{array}$ & $\begin{array}{c}0.266 \\
(0.212)\end{array}$ & $\begin{array}{c}0.273 \\
(0.211)\end{array}$ & $\begin{array}{r}0.353^{\dagger} \\
(0.208)\end{array}$ & $\begin{array}{c}0.336 \\
(0.209)\end{array}$ & $\begin{array}{c}0.256 \\
(0.214)\end{array}$ & $\begin{array}{c}0.278 \\
(0.212)\end{array}$ & $\begin{array}{c}0.318 \\
(0.209)\end{array}$ \\
\hline$V L$ & $\begin{array}{r}0.338^{\dagger} \\
(0.202)\end{array}$ & $\begin{array}{c}0.244 \\
(0.206)\end{array}$ & $\begin{array}{c}0.258 \\
(0.204)\end{array}$ & $\begin{array}{c}0.323 \\
(0.201)\end{array}$ & $\begin{array}{c}0.288 \\
(0.200)\end{array}$ & $\begin{array}{c}0.228 \\
(0.203)\end{array}$ & $\begin{array}{c}0.262 \\
(0.205)\end{array}$ & $\begin{array}{c}0.270 \\
(0.201)\end{array}$ \\
\hline $\mathrm{CO}$ & $\begin{array}{c}0.365 \\
(0.297)\end{array}$ & $\begin{array}{c}0.368 \\
(0.299)\end{array}$ & $\begin{array}{c}0.355 \\
(0.303)\end{array}$ & $\begin{array}{c}0.398 \\
(0.296)\end{array}$ & $\begin{array}{c}0.391 \\
(0.295)\end{array}$ & $\begin{array}{c}0.373 \\
(0.301)\end{array}$ & $\begin{array}{c}0.369 \\
(0.299)\end{array}$ & $\begin{array}{c}0.385 \\
(0.293)\end{array}$ \\
\hline$L C$ & $\begin{array}{c}0.396 \\
(0.247)\end{array}$ & $\begin{array}{r}0.401^{\dagger} \\
(0.242)\end{array}$ & $\begin{array}{c}0.391 \\
(0.241)\end{array}$ & $\begin{array}{c}0.336 \\
(0.249)\end{array}$ & $\begin{array}{c}0.344 \\
(0.244)\end{array}$ & $\begin{array}{c}0.367 \\
(0.239)\end{array}$ & $\begin{array}{c}0.373 \\
(0.243)\end{array}$ & $\begin{array}{c}0.335 \\
(0.248)\end{array}$ \\
\hline$I P O$ & $\begin{array}{c}-0.539^{* * *} \\
(0.0986)\end{array}$ & $\begin{array}{c}-0.560^{* * *} \\
(0.101)\end{array}$ & $\begin{array}{c}-0.566^{* * *} \\
(0.101)\end{array}$ & $\begin{array}{c}-0.539 * * * \\
(0.0994)\end{array}$ & $\begin{array}{c}-0.540 * * * \\
(0.0998)\end{array}$ & $\begin{array}{c}-0.564^{* * *} \\
(0.102)\end{array}$ & $\begin{array}{c}-0.550^{* * *} \\
(0.0998)\end{array}$ & $\begin{array}{c}-0.439^{* * *} \\
(0.104)\end{array}$ \\
\hline LnPat & $\begin{array}{c}0.0621^{*} \\
(0.0300)\end{array}$ & $\begin{array}{r}0.0501^{\dagger} \\
(0.0304)\end{array}$ & $\begin{array}{c}0.0437 \\
(0.0305)\end{array}$ & $\begin{array}{c}0.0531^{\dagger} \\
(0.0300)\end{array}$ & $\begin{array}{c}0.0443 \\
(0.0301)\end{array}$ & $\begin{array}{c}0.0339 \\
(0.0306)\end{array}$ & $\begin{array}{c}0.0435 \\
(0.0305)\end{array}$ & $\begin{array}{c}0.0446 \\
(0.0302)\end{array}$ \\
\hline PatSqr & $\begin{array}{c}-0.0737 * \\
(0.0334)\end{array}$ & $\begin{array}{c}-0.0916^{*} \\
(0.0362)\end{array}$ & $\begin{array}{c}-0.0811^{*} \\
(0.0354)\end{array}$ & $\begin{array}{c}-0.0750^{*} \\
(0.0338)\end{array}$ & $\begin{array}{c}-0.0779 * \\
(0.0345)\end{array}$ & $\begin{array}{c}-0.0860^{*} \\
(0.0362)\end{array}$ & $\begin{array}{c}-0.0734 * \\
(0.0352)\end{array}$ & $\begin{array}{c}-0.0746^{*} \\
(0.0345)\end{array}$ \\
\hline$D g r$ & & $\begin{array}{l}0.302 * * * \\
(0.0574)\end{array}$ & $\begin{array}{l}0.455^{* * *} \\
(0.0833)\end{array}$ & & & $\begin{array}{l}0.373^{* * *} \\
(0.0877)\end{array}$ & $\begin{array}{l}0.538^{* * *} \\
(0.104)\end{array}$ & \\
\hline$D g r S q r$ & & & $\begin{array}{r}-0.0274 * * \\
(0.00919)\end{array}$ & & & $\begin{array}{r}-0.0195^{\dagger} \\
(0.0108)\end{array}$ & $\begin{array}{c}-0.0339 * \\
(0.0154)\end{array}$ & \\
\hline LnEig & & & & $\begin{array}{l}4.738^{* *} \\
(1.540)\end{array}$ & $\begin{array}{l}16.46^{* * * *} \\
(3.445)\end{array}$ & $\begin{array}{l}12.68 * * * \\
(3.707)\end{array}$ & & $\begin{array}{l}21.49 * * * \\
(4.397)\end{array}$ \\
\hline LnEigSqr & & & & & $\begin{array}{c}-0.0679^{* * *} \\
(0.0181)\end{array}$ & $\begin{array}{c}-0.0574^{* *} \\
(0.0214)\end{array}$ & & $\begin{array}{c}-0.0936^{* *} \\
(0.0295)\end{array}$ \\
\hline$I p o \times D g r$ & & & & & & & $\begin{array}{r}-0.264^{\dagger} \\
(0.136)\end{array}$ & \\
\hline$I p o \times D g r S q r$ & & & & & & & $\begin{array}{c}0.0274 \\
(0.0211)\end{array}$ & \\
\hline Ipo $\times$ Eig & & & & & & & & $\begin{array}{c}-21.09^{*} \\
(9.390)\end{array}$ \\
\hline Ipo $\times$ LnEigSqr & & & & & & & & $\begin{array}{r}0.0914^{*} \\
(0.0406)\end{array}$ \\
\hline Cons & $\begin{array}{c}-1.255^{* * *} \\
(0.122)\end{array}$ & $\begin{array}{c}-1.565^{* * *} \\
(0.135)\end{array}$ & $\begin{array}{c}-1.727 * * * \\
(0.151)\end{array}$ & $\begin{array}{c}-1.264^{* * *} \\
(0.122)\end{array}$ & $\begin{array}{c}-1.259^{* * *} \\
(0.122)\end{array}$ & $\begin{array}{c}-1.642^{* * *} \\
(0.154)\end{array}$ & $\begin{array}{c}-1.825^{* * *} \\
(0.167)\end{array}$ & $\begin{array}{c}-1.265^{* * *} \\
(0.122)\end{array}$ \\
\hline Wald $\mathrm{Chi}^{2}$ & 189.56 & 214.09 & 219.43 & 192.09 & 173.84 & 202.64 & 237.91 & 219.87 \\
\hline Pseudo $R^{2}$ & 0.1588 & 0.1718 & 0.1740 & 0.1626 & 0.1697 & 0.1799 & 0.1759 & 0.1727 \\
\hline $\begin{array}{c}\text { Log_pseudo } \\
\text { likelihood }\end{array}$ & -905.66 & -891.61 & -889.23 & -901.54 & -893.89 & -882.93 & -887.17 & -890.63 \\
\hline$N$ & 2083 & 2083 & 2083 & 2083 & 2083 & 2083 & 2083 & 2083 \\
\hline
\end{tabular}

Standard errors in parentheses. ${ }^{\dagger} p<0.10,{ }^{*} p<0.05,{ }^{* *} p<0.01,{ }^{* * *} p<0.001$. 
likely to be acquired. The coefficient of Nat is positive, meaning that US firms are more likely to be acquired. Previous collaborations (PrevColl), as largely expected, have a positive impact on the likelihood of being acquired. The Size of the firm is also significant. Indeed, where the category microfirms (MI) is assumed as a baseline, the results show that having smaller dimensions, until the category small firms (SM), has a positive and significant effect on the probability of being acquired. In accordance with the stream of literature that considers IPO as a source of resources, we get a negative and significant impact of the IPO on the likelihood of being acquired. Finally, in line with our conjecture, patents have an inverted U-shaped effect on the likelihood of being acquired.

In Hypothesis 1, we argued that direct ties have an inverted U-shaped effect on the firm's probability of being acquired; the coefficient of $D g r$ is positive and significant in model 2, while the coefficient of $D g r S q r$ is negative and significant in model 3, thus supporting Hypothesis 1. Hypothesis 2 argued that network prominence, measured through the firm's eigenvector centrality, has an inverted U-shaped effect on the firm's probability of being acquired; the coefficient of LnEig is positive and significant in model 4 , while the coefficient of LnEigSqr is negative and significant in model 5, thus supporting Hypothesis 2. Moreover, Hypothesis 1 and Hypothesis 2 received further confirmation from model 6 where all the explanatory variables ( $D g r, D g r S q r$, LnEig and LnEigSqr) are introduced together, and they continue to be highly significant and with the expected signs.

Figure 3 is a graphical representation of the results concerning Hypothesis 1 and Hypothesis 2. An inverted U-shaped relationship exists if $Y$ first increases with $X$ at a decreasing rate to reach a maximum, after which $Y$ decreases at an increasing rate. The point at which the curve attains its maximum is the 'turning point', and it needs to be located well within the data range (Lind and Mehlum, 2010). We tested this assumption following the procedure described in the recent paper by Haans, Pieters and $\mathrm{He}$ (2015) on the use of U-shaped relations in strategic management literature, and affirmed our results as shown in Figures $3 \mathrm{a}$ and $3 \mathrm{~b}$.

Models 7 and 8 exhibit a negative, and significant, linear interaction between IPO and,respectively, $D g r$ and LnEig. The interaction between $D g r S q r$ and IPO in model 7 is not sig- nificant, while the interaction between $I P O$ and LnEigSqr is significant and positive. These results confirm, only for LnEig, our prediction of Hypothesis 3 that an IPO makes the relation between prominence and the probability of being acquired weaker, when prominence does not assume strong values. Indeed, as clearly shown in Figure 4, for moderate levels of eigenvector centrality, the green dots are significantly under the red ones, meaning that when the firm goes through an IPO, the probability of being acquired is significantly lower than when it does not go through an IPO. However, when the eigenvector centrality reaches high levels, the negative moderation effect of the IPO is attenuated as predicted by Hypothesis 3 .

\section{Discussion and conclusion}

Our study offers three contributions to the SC literature. First, to the best of our knowledge, this is the first research to address the impact of the firm's network positions on its likelihood of being acquired. Previous studies in SC literature have examined the firm's survival (Brüderl and Preisendörfer, 1998; Mitchell and Singh, 1996; Uzzi, 1996; Watson, 2007), the firm's dissolution (Pennings, Lee and Van Witteloostuijn, 1998), and the firm's propensity to make acquisitions or mergers (Haunschild, 1993; Hoang, 1997; Lin et al., 2009; Yang, Lin and Peng, 2011). Our study is aligned with prior findings that show a positive impact of SC on the firm's survival (e.g. Brüderl and Preisendörfer, 1998), and it extends previous research showing how and why the firm's direct ties and prominence provide a signal that catalyzes its acquisition. We explain the mechanism through which this happens, i.e. how the visibility-enhancing effect of direct ties is subsequently dampened by the network resources effect, resulting in an overall inverted U-shaped relation. Similarly, the quality signaling effect of prominence is subsequently reversed by network-status resulting in an overall inverted U-shaped relation.

Although these two centrality features exhibit the same behaviors, as Figures $3 \mathrm{a}$ and $3 \mathrm{~b}$ and a comparison of their standardized coefficients show, the influence of the eigenvector centrality (a standardized coefficient of -0.218) seems to be much stronger than that of the degree centrality (a standardized coefficient of -0.088) in decreasing a firm's probability of being acquired. This result is 

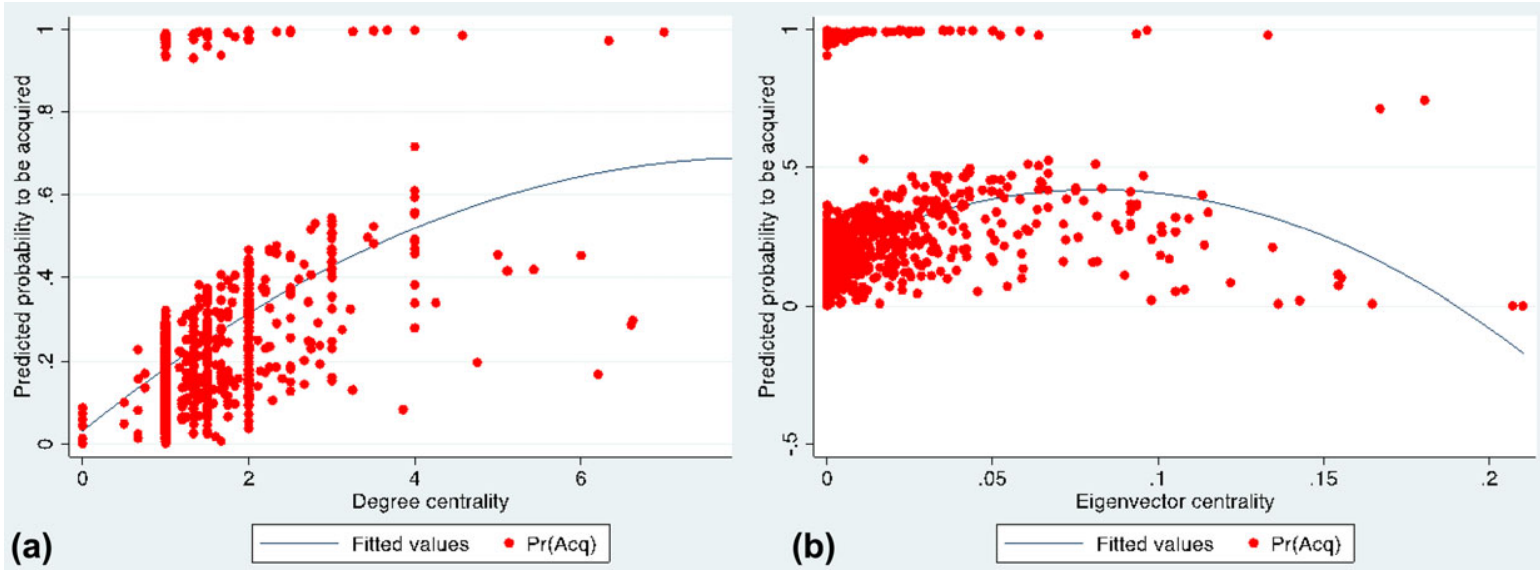

Figure 3. (a) Probability of being acquired vs. degree centrality; (b) probability of being acquired vs. eigenvector centrality

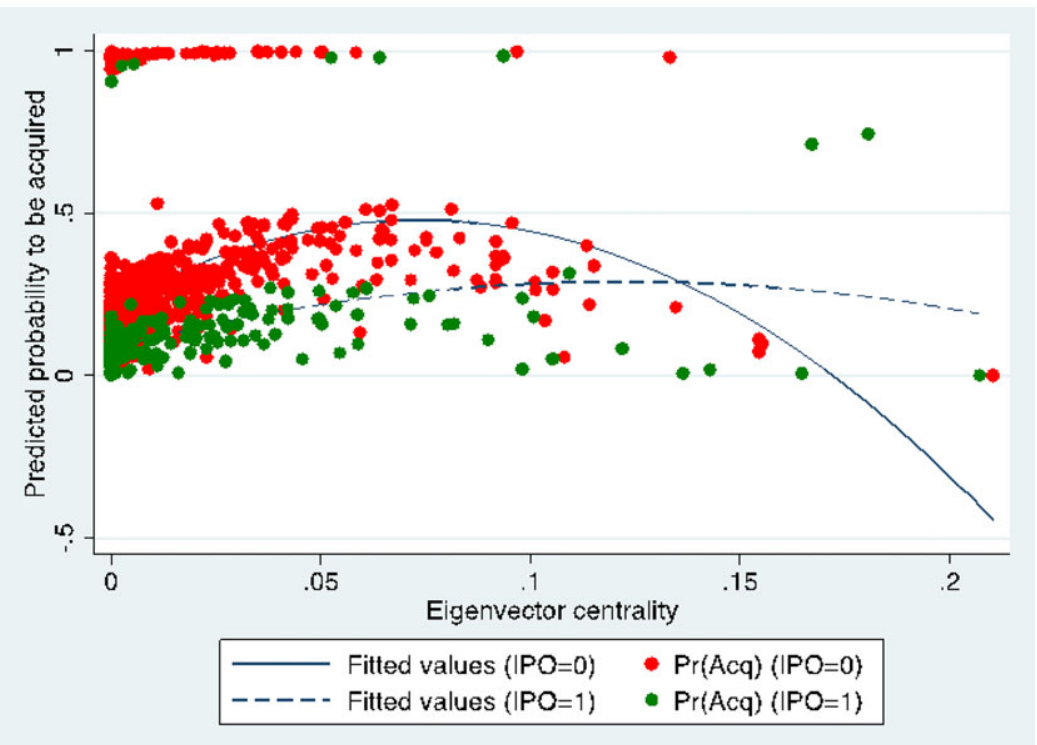

Figure 4. IPO effects on the probability of being acquired vs. eigenvector centrality

quite interesting considering that, for instance, neither Ahuja (2000) nor Salman and Saives (2005) found appreciable differences between direct centrality and eigenvector centrality in driving innovation outputs such as patents. Our study seems to indicate that, at least with respect to acquisition probabilities, they have different strengths. To explain this finding, we suggest that, on the one hand, direct ties expose the firm directly to partners that may be possible buyers; thus, even if the firm gains access to resources through its network, its exposure to possible buyers has a relatively more telling effect. On the other hand, highly prominent firms may enjoy advantages of status and are less ex- posed to effects of direct relations. Another reason could be that the status effect is just stronger than the resource effect in protecting the firm from being acquired. For instance, the benefits from network status extend to a wider portion of the network, while access to resources is largely provided by direct ties limited to the neighborhood of the ego firm. This different explanation of the findings calls for deeper research.

These results have important managerial implications - at least in the biopharmaceutical context. Direct ties and prominence are a double-edged sword. A firm's inter-firm network position can enhance its visibility and signal its quality, and thus 
improve its likelihood of being acquired. At the same time, as the firm achieves strong centrality positions, it is likely that the network also provides sufficient resources and status to assure the independence of the firm. Furthermore, as previously mentioned, prominence seems to provide a better defense against acquisitions.

Second, our study enhances the SC literature by including $\mathrm{SC}$ as a source of valuable signals for firms. Indeed, while the SC literature has considered relational embeddedness as a source of valuable signals (e.g. Gulati and Higgins, 2003), only the recent study by Ozmel, Reuer and Gulati (2013) has examined structural embeddedness features as a source of signals for a firm. However, they limited the analysis to one dimension of structural embeddedness - the firm's prominence, i.e. the eigenvector centrality feature. Our study builds on their work and shows that direct ties also signal the value of the focal firm.

Furthermore, our work shows how even moderate values of direct ties and network prominence are able to provide a visibility-enhancing signal. The signaling effect of a firm's network position has an asymptotic behavior whose marginal impact on the likelihood of its acquisition progressively decreases, the more the firm's two network positions strengthen. Moreover, our study suggests a dynamic of the signaling effect of network positions. At moderate levels of direct ties and network prominence, the firm acquires visibility and signals its quality. However, both visibility and quality signals marginally decrease in their importance, at least in increasing the firm's acquisition probability, once they reach stronger values.

Finally, by analyzing the interactions between the firm's network positions and whether or not it undertakes an IPO, we contribute to a better understanding of the impact of multiple signals on the firm's likelihood of being acquired. Our results show that an IPO subsumes the signaling impact of prominence and weakens its effect on the firm's probability of being acquired. This result adds new knowledge to the literature that places IPOs in relation to acquisition probabilities. In line with the literature on IPO as a source of resources and status that places the firm in a better position to resist acquisitions (e.g. Field, 1999), we show how, for moderate levels of prominence, an IPO acts as a perfect substitute for the visibility-enhancing and quality signal provided by the network position. However, higher values of network prominence signal the status of the firm (Brennan and Franks, 1997; Jain and Kini, 1999), and allow the firm to stand out from the crowd of IPO firms, and thereby improve the likelihood of being acquired. Direct centrality though, even when it directly exposes the firm to possible buyers (Hypothesis 3), does not seem to provide complementing signals for either IPO or non-IPO firms. Of course, these results have significant managerial implications. First, IPO events completely change the impact of direct ties and prominence on the firm's likelihood of being acquired, indicating that managers need to re-consider the impact of their network strategies when dealing with an IPO. Second, direct ties and prominence have slightly different interactions, with prominence the only variable that is really more involved in interaction with IPO.

This study has some limitations that, in turn, present future opportunities for development of this work. First, we focused on direct ties and prominence as structural embeddedness network features; however, bridging structural holes are a network feature that has raised several research contributions among SC scholars (e.g. Ahuja, 2000; Zaheer and Bell, 2005). Thus, understanding the effect of structural holes on the likelihood of being acquired would complete the theoretical framework. Second, our study did not consider a relational perspective (i.e. the typology of the relation) of the inter-firm agreements, as this issue has been previously addressed in the alliance literature (e.g. Afuah, 2001; Anderson et al., 2001; Haunschild, 1994). Our focus was on network positioning. However, further studies can investigate how relational and network position influence each other with respect to acquisition probability. Third, we did not consider the level of success of an IPO. A much better operationalization of the IPO variable could offer a more comprehensive understanding of the quality of the IPO signal. Finally, because the intention was to analyze the relationship between the firm's network position in its inter-firm network and the probability of being acquired, this study focused on the biopharmaceutical industry, in which inter-firm networks are a relatively common phenomenon (Rothaermel, 2001), and the company sale is more than an exit strategy (Arora and Gambardella, 1990). Thus, although this approach is appropriate, it would be unwise to generalize the findings too broadly to other industries and cultural contexts. 


\section{References}

Afuah, A. (2001). 'Dynamic boundaries of the firm: are firms better off being vertically integrated in the face of a technological change?', Academy of Management journal, 44, pp. 1211-1228.

Ahuja, G. (2000). 'Collaboration networks, structural holes, and innovation: a longitudinal study', Administrative Science Quarterly, 45, pp. 425-455.

Al-Laham, A., T. L. Amburgey and K. Bates (2008). 'The dynamics of research alliances: examining the effect of alliance experience and partner characteristics on the speed of alliance entry in the biotech industry', British Journal of Management, 19, pp. 343-364.

Ali-Yrkkö, J., A. Hyytinen and M. Pajarinen (2005). 'Does patenting increase the probability of being acquired? Evidence from cross-border and domestic acquisitions', Applied Financial Economics, 15, pp. 1007-1017.

Anand, B. N. and T. Khanna (2000). 'Do firms learn to create value? The case of alliances', Strategic Management Journal, 21, pp. 295-315.

Anderson, H., V. Havila and A. Salmi (2001). 'Can you buy a business relationship?: On the importance of customer and supplier relationships in acquisitions', Industrial Marketing Management, 30, pp. 575-586.

Arora, A. and A. Gambardella. (1990). 'Complementarity and external linkages: the strategies of the large firms in biotechnology', Journal of Industrial Economics, 38, pp. 361-79.

Balakrishnan, S. and M. P. Koza (1993). 'Information asymmetry, adverse selection and joint-ventures: theory and evidence', J. Economic Behavior \& Organization, 20, pp. 99-117.

Barkema, H. and F. Vermeulen (1998). 'International expansion through start-up or acquisition: a learning perspective', Academy of Management Journal, 41, pp. 7-26.

Baum, J. A. and B. S. Silverman (2004). 'Picking winners or building them? Alliance, intellectual, and human capital as selection criteria in venture financing and performance of biotechnology startups', Journal of Business Venturing, 19, pp. 411-436.

Baum, J., T. Calabrese and B. S. Silverman (2000). 'Don't go it alone: alliance networks and startups' performance in Canadian biotechnology', Strategic Management Journal, 21, pp. 267-294.

Benjamin, B. A. and J. M. Podolny (1999). 'Status, quality, and social order in the California wine industry', Administrative Science Quarterly, 44, pp. 563-589.

Bergh, D. D., B. L. Connelly, D. J. Ketchen and L. M. Shannon (2014). 'Signaling theory and equilibrium in strategic management research: an assessment and a research agenda', Journal of Management Studies, 51, pp. 1334-1360.

Billitteri, C., G. Lo Nigro and G. Perrone. (2013). 'Drivers influencing the governance of inter-firm relationships in the biopharmaceutical industry: an empirical survey in the Italian context', Technology Analysis and Strategic Management, 25, pp. 107-126.

Birch, K. (2008). 'Alliance-driven governance: applying a global commodity chains approach to the U.K. biotechnology industry', Economic Geography, 84, pp. 83-103.

Bonacich, P. (1987). 'Power and centrality: a family of measures', American Journal of Sociology, 92, pp. 1170-1182.

Borgatti, S. P., G. M Everett and L. C. Freeman. (2002). Ucinet 6 for Windows. Harvard, MA: Analytic Technologies.
Bradfield, R. and H. El-Sayed (2009). 'Four scenarios for the future of the pharmaceutical industry', Technology Analysis \& Strategic Management, 21, pp. 195-212.

Brennan, M. J. and J. Franks (1997). 'Underpricing, ownership and control in initial public offerings of equity securities in the UK', Journal of Financial Economics, 45, pp. 391-413.

Brüderl, J. and P. Preisendörfer (1998). 'Network support and the success of newly founded business', Small Business Economics, 10, pp. 213-225.

Bruton, G. D., S. Chahine and I. Filatotchev (2009). 'Founders, private equity investors, and underpricing in entrepreneurial IPOs', Entrepreneurship Theory and Practice, 33, pp. 909-928.

Busenitz, L. W., J. O. Fiet and D. D. Moesel (2005). 'Signaling in venture capitalist-new venture team funding decisions: does it indicate long-term venture outcomes?', Entrepreneurship Theory and Practice, 29, pp. 1-12.

BusinessWire (2009). 'Asterand announces agreement to acquire BioSeek. Next step in consolidating Asterand's leadership position in the global human tissue market', November. Available at http://www.businesswire.com/news/ home/20091118005214/en/Asterand-Announces-AgreementAcquire-BioSeek

Certo, S. T. (2003). 'Influencing initial public offering investors with prestige: signaling with board structures', Academy of Management Review, 28, pp. 432-446.

Certo, S. T., C. M. Daily and D. R. Dalton (2001). 'Signaling firm value through board structure: an investigation of initial public offerings'. Entrepreneurship Theory and Practice, 26, pp. 33-50.

Chung, S. A., H. Singh and K. Lee (2000). 'Complementarity, status similarity and social capital as drivers of alliance formation', Strategic Management Journal, 21, pp. 1-22.

Coff, R. W. (2002). 'Human capital, shared expertise, and the likelihood of impasse in corporate acquisitions', Journal of Management, 28, pp. 107-128.

Cohen, B. D. and Dean, T. J. (2005). 'Information asymmetry and investor valuation of IPOs: top management team legitimacy as a capital market signal', Strategic Management Journal, 26, pp. 683-690.

Connelly, B. L., S. T. Certo, R. D. Ireland and C. R. Reutzel (2011). 'Signaling theory: a review and assessment', Journal of Management, 37, pp. 39-67.

Danzon, P. M., A. Epstein and S. Nicholson (2007). 'Mergers and acquisitions in the pharmaceutical and biotech industries', Managerial and Decision Economics, 28, pp. 307-328.

DiMasi, J. A., R. W. Hansen and H. G. Grabowski (2003). 'The price of innovation: new estimates of drug development cost', Journal of Health Economics, 22, pp. 151-185.

Dyer, J. H. and H. Singh (1998). 'The relational view: cooperative strategy and sources of interorganizational competitive advantage', Academy of Management Review 23, pp. 660-679.

Elitzur, R. and A. Gavious (2003). 'Contracting, signaling, and moral hazard: a model of entrepreneurs, "angels," and venture capitalists', Journal of Business Venturing, 18, pp. 709-725.

Evans, D. S. (1987). 'The relationship between firm growth, size, and age: estimates for 100 manufacturing industries', Journal of Industrial Economics, 35, pp. 567-581.

Field, L. C. (1999). 'Control considerations of newly public firms: the implementation of antitakeover provisions and dual class shares before the IPO'. Working paper, Penn State University. 
Available at http://dx.doi.org/10.2139/ssrn.150488 [accessed30 November 2015].

Field, L. C. and J. M. Karpoff (2002). 'Takeover defenses of IPO firms', Journal of Finance, 57, pp. 1857-1889.

Filatotchev, I. and K. Bishop (2002). 'Board composition, share ownership, and "underpricing” of U.K. IPO firms', Strategic Management Journal, 23, pp. 941-955.

Gilsing, V. A., B. Nooteboom, W. Vanhaverbeke, G. M. Duysters and A. P. van den Oord (2008). 'Network embeddedness and the exploration of novel technologies: technological distance, betweenness centrality and density', Research Policy, 37, pp. 1717-1731.

Goozner, M. (2004). The $\$ 800$ Million Pill: The Truth Behind the Cost of New Drugs. Berkeley, CA: University of California Press.

Grandori, A. and G. Soda (1995). 'Inter-firm networks: antecedents, mechanisms and forms', Organization Studies, 16, pp. $183-214$.

Gulati, R. (1995). 'Does familiarity breed trust? The implications of repeated choice for contractual ties in alliances', Academy of Management Journal, 38, pp. 85-112.

Gulati, R. (1998). 'Alliances and networks', Strategic Management Journal, 19, pp. 293-317.

Gulati, R. (1999). 'Network location and learning: the influence of network resources and firm capabilities on alliance formation', Strategic Management Journal, 20, pp. 397-420.

Gulati, R. and Higgins, M. C. (2003). 'Which ties matter when? The contingent effects of interorganizational partnerships on IPO success', Strategic Management Journal, 24, pp. 127-144.

Gulati, R., N. Nohria and A. Zaheer (2000) 'Strategic networks', Strategic Management Journal, 21, pp. 203-215.

Haans, R. F., C. Pieters and Z. L. He (2015). 'Thinking about $\mathrm{U}$ : theorizing and testing U- and inverted U-shaped relationships in strategy research', Strategic Management Journal, doi: 10.1002/smj.2399.

Hagedoorn, J. and G. Duysters (2002). 'External sources of innovative capabilities: the preference for strategic alliances or mergers and acquisitions', Journal of Management Studies, 39, pp. 167-188.

Hagedoorn, J., N. Roijakkers and H. Kranenburg (2006). 'Interfirm R\&D networks: the importance of strategic network capabilities for high-tech partnership formation', British Journal of Management, 17, pp. 39-53.

Haunschild, P. R. (1993). 'Interorganizational imitation: the impact of interlocks on corporate acquisition activity', Administrative Science Quarterly, 38, pp. 564-592.

Haunschild, P. R. (1994). 'How much is that company worth?: Interorganizational relationships, uncertainty, and acquisition premiums', Administrative Science Quarterly, 39, pp. 391-411.

Helmers, C. and M. Rogers (2011). 'Does patenting help hightech start-ups?', Research Policy, 40, pp. 1016-1027.

Higgins, M. C. and R. Gulati (2006). 'Stacking the deck: the effects of top management backgrounds on investor decisions', Strategic Management Journal, 27, pp. 1-25.

Higgins, M. J. and D. Rodriguez (2006). 'The outsourcing of R\&D through acquisitions in the pharmaceutical industry', Journal of Financial Economics, 80, pp. 351-383.

Hoang, H. (1997). 'The consequences of network participation for acquisition and alliance activity in the biotechnology industry', Academy of Management Proceedings, 1, pp. 267-271.
Hoetker, G. (2007). 'The use of logit and probit models in strategic management research: critical issues', Strategic Management Journal, 28, pp. 331-343.

Holcomb, T.R. and M. A. Hitt (2007). 'Toward a model of strategic outsourcing', Journal of Operations Management, 25, pp. $464-481$.

Hovakimian, A. and I. Hutton (2010). 'Merger-motivated IPOs', Financial Management, 39, pp. 1547-1573.

Hsu, D. H. and R. H. Ziedonis (2008). 'Patents as quality signal for entrepreneurial ventures', Academy of Management Proceedings, 1, pp. 1-6.

Hsu, D. H. and R. H. Ziedonis (2013). 'Resources as dual sources of advantage: implications for valuing entrepreneurial-firm patents', Strategic Management Journal, 34, pp. 761-781.

IMAP (2014). Global Pharma \& Biotech M\&A Report. IMAP.

Inkpen, A. C. (1998). 'Learning and knowledge acquisition through international strategic alliances', Academy of Management Executive, 12, pp. 69-80.

Jain, B. A. and O. Kini (1999). 'The life cycle of initial public offering firms', Journal of Business Finance \& Accounting, 26, pp. 1281-1307.

Jain, B. A., N. Jayaraman and O. Kini (2008). 'The path-toprofitability of Internet IPO firms', Journal of Business Venturing, 23, pp. 165-194.

Janney, J. J. and T. B. Folta (2003). 'Signaling through private equity placements and its impact on the valuation of biotechnology firms', Journal of Business Venturing, 18, pp. 361-380.

Janney, J. J. and T. B. Folta (2006). 'Moderating effects of investor experience on the signaling value of private equity placements', Journal of Business Venturing, 21, pp. 27-44.

Jensen, M. (2003). 'The role of network resources in market entry: commercial banks' entry into investment banking, 19911997', Administrative Science Quarterly, 48, pp. 466-497.

Kale, P. and H. Singh. (2007). 'Building firm capabilities through learning: the role of the alliance learning process in alliance capability and firm-level alliance success', Strategic Management Journal, 28, pp. 981-1000.

Koka, B. R. and J. E. Prescott. (2002). 'Strategic alliances as social capital: a multidimensional view', Strategic Management Journal, 23, pp. 795-816.

Koka, B. R. and J. E. Prescott (2008). 'Designing alliance networks: the influence of network position, environmental change, and strategy on firm performance', Strategic Management Journal, 29, pp. 639-661.

Lerner, J. (1995). 'Venture capitalists and the oversight of private firms', Journal of Finance, 50, pp. 301-318.

Lin, Z., M. W. Peng, H. Yang and S. L. Sun (2009). 'How do networks and learning drive M\&As? An institutional comparison between China and the United States', Strategic Management Journal, 30, pp. 1113-1132.

Lind, J. T. and H. Mehlum (2010). 'With or without U? The appropriate test for a U-shaped relationship', Oxford Bulletin of Economics and Statistics, 72, pp. 109-118.

Long, C. (2002). 'Patent signals', University of Chicago Law Review, 69, pp. 625-679.

Long, J.S. (1997). Regression Models for Categorical and Limited Dependent Variables. Advanced Quantitative Techniques in the Social Sciences. Thousand Oaks, CA: Sage Publications.

Mazzola, E., M. Bruccoleri and G. Perrone (2015). 'Supply chain of innovation and new product development', Journal of Purchasing and Supply Management, 21, pp. 273-284. 
Mazzola, E., G. Perrone and D. S. Kamuriwo (2015). 'Network embeddedness and new product development in the biopharmaceutical industry: the moderating role of open innovation flow', International Journal of Production Economics, 160, pp. 106-119.

McPherson, M., L. Smith-Lovin and J. M. Cook (2001). 'Birds of a feather: homophily in social networks', Annual Review of Sociology, 27, pp. 415-444.

Mitchell, W. and K. Singh (1996). 'Survival of businesses using collaborative relationships to commercialize complex goods', Strategic Management Journal, 17, pp. 169-195.

Mowery, D.C., J. E. Oxley and B. S. Silverman (1996). 'Strategic alliances and interfirm knowledge transfer', Strategic Management Journal, 17, pp. 77-91.

Nicholson, S., P. M. Danzon and J. McCullough (2005). 'Biotech-pharmaceutical alliances as a signal of asset and firm quality', Journal of Business, 78, pp. 1433-1464.

Ozmel, U., J. Reuer and R. Gulati (2013). 'Signals across multiple networks: how venture capital and alliance networks affect interorganizational collaboration', Academy of Management Journal, 56, pp. 852-866.

Parkhe, A. (1993). 'Strategic alliance structuring: a game theoretic and transaction cost examination of interfirm cooperation', Academy of Management Journal, 36, pp. 794-829.

Pennings, J. M., K. Lee and A. Van Witteloostuijn (1998). 'Human capital, social capital, and firm dissolution', Academy of Management Journal, 41, pp. 425-440.

Pisano, G. P. (1990). 'The R\&D boundaries of the firm: an empirical analysis', Administrative Science Quarterly, 35, pp. 153176.

Podolny, J. M. (1993). 'A status-based model of market competition', American Journal of Sociology, 98, pp. 829-872.

Podolny, J. M. (2001). 'Networks as the pipes and prisms of the market', American Journal of Sociology, 107, pp. 33-60.

Pollock, T. G. and R. Gulati (2007). 'Standing out from the crowd: the visibility-enhancing effects of IPO-related signals on alliance formation by entrepreneurial firms', Strategic Organization, 5, pp. 339-372.

Powell, R. G. (1997). 'Modelling takeover likelihood', Journal of Business Finance and Accounting, 24, pp. 1009-1029.

Powell, W. W. and P. Brantley. (1992). 'Competitive cooperation in biotechnology: learning through networks?' In N. Nohria and R. Eccles (eds), Networks and Organizations, pp. 366-394. Boston, MA: Harvard Business School Press.

Powell, W.W., K. W. Koput, and L. Smith-Doerr. (1996). 'Interorganizational collaboration and the locus of control of innovation: networks of learning in biotechnology', Administrative Science Quarterly, 41, pp. 116-145.

Ragozzino, R. and J. J. Reuer (2007). 'Initial public offerings and the acquisition of entrepreneurial firms', Strategic Organization, 5, pp. 155-176.

Rao, H., G. F. Davis and A. Ward (2000). 'Embeddedness, social identity and mobility: why firms leave the NASDAQ and join the New York Stock Exchange', Administrative Science Quarterly, 45, pp. 268-292.

Ring, P.S. and A. H. Van de Ven (1992). 'Structuring cooperative relationship between organizations', Strategic Management Journal, 13, pp. 483-498.

Rockoff, J. (2015). 'Pfizer weighs splitting up new drug behemoth', Wall Street Journal. Available at http://www.wsj.com/ articles/pfizer-and-allergan-to-merge-in-huge-inversion-deal1448280652 [accessed 30 November 2015].
Rothaermel, F. T. (2001). 'Complementary assets, strategic alliances, and the incumbent's advantage: an empirical study of industry and firm effects in the biopharmaceutical industry', Research Policy, 30, pp. 1235-1251.

Salman, N. and A. L. Saives. (2005). 'Indirect networks: an intangible resource for biotechnology innovation', $R \& D$ Management, 35, pp. 203-215.

Schilling, M. and C. Phelps. (2007). 'Interfirm collaboration networks and knowledge creation: the impact of large scale network structure on firm innovation', Management Science, 53, pp. 1113-1126.

Shipilov, A. V. and S. Li. (2008). 'Can you have your cake and eat it too? Structural holes' influence on status accumulation and market performance in collaborative networks', Administrative Science Quarterly, 58, pp. 73-108.

Soh, P.-H. (2003). 'The role of networking alliances in information acquisition and its implication for new product performance', Journal of Business Venturing, 18, pp. 727-744.

Soh, P. H., I. P. Mahmood and W. Mitchell (2004). 'Dynamic inducements in R\&D investment: market signals and network locations', Academy of Management Journal, 47, pp. 907-917.

Spence, M. (1973). 'Job market signaling', Quarterly Journal of Economics, 87, pp. 355-374.

Spence, M. (2002). 'Signaling in retrospect and the informational structure of markets', American Economic Review, 92, pp. 434 459.

Stevens, J. (1992). Applied Multivariate Statistics for the Social Sciences. Hillsdale, NJ: Lawrence Erlbaum Associates.

Stoughton, N. M., K. P. Wong and J. Zechner (2001). 'IPOs and product quality (digest summary)', Journal of Business, 74, pp. $375-408$.

Stuart, T. E. (2000). 'Interorganizational alliances and the performance of firms: a study of growth and innovation rates in a high-technology industry', Strategic Management Journal, 21, pp. 791-811.

Stuart, T. E., H. Hoang and R. C. Hybels (1999). 'Interorganizational endorsements and the performance of entrepreneurial ventures', Administrative Science Quarterly, 44, pp. 315-349.

Uzzi, B. (1996). 'The sources and consequences of embeddedness for the economic performance of organizations: the network effect', American Sociological Review, 61, pp. 674-698.

Vanhaverbeke, W., G. Duysters and N. Noorderhaven (2002). 'External technology sourcing through alliances or acquisitions: an analysis of the application-specific integrated circuits industry', Organization Science, 13, pp. 714-733.

Vanhaverbeke, W., V. Gilsing, B. Beerkens and G. Duysters (2009). 'The role of alliance network redundancy in the creation of core and non-core technologies: a local action approach', Journal of Management Studies, 46, pp. 215-244.

Vanhaverbeke, W., V. Gilsing, and G. Duysters (2012). 'Competence and governance in strategic collaboration: the differential effect of network structure on the creation of core and noncore technology', Journal of Product Innovation Management, 29, pp. 784-802.

Villalonga, B. and A. M. McGahan (2005). 'The choice among acquisitions, alliances, and divestitures', Strategic Management Journal, 26, pp. 1183-1208.

Wagner, S. and I. Cockburn (2010). 'Patents and the survival of Internet-related IPOs', Research Policy, 39, pp. 214-228.

Wang, L. and E. J. Zajac (2007). 'Alliance or acquisition? A dyadic perspective on interfirm resource combinations', Strategic Management Journal, 28, pp. 1291-1317. 
Watson, J. (2007). 'Modeling the relationship between networking and firm performance', Journal of Business Venturing, 22, pp. 852-874.

Wincent, J., S. Thorgren and S. Anokhin (2013). 'Managing maturing government-supported networks: the shift from monitoring to embeddedness controls', British Journal of Management, 24, pp. 480-497.

Wu, W.-P. (2008). 'Dimensions of social capital and firm competitiveness improvement: the mediating role of information sharing', Journal of Management Studies, 45, pp. 122-146.

Yang, H., Z. J. Lin and M. W. Peng (2011). 'Behind acquisitions of alliance partners: exploratory learning and network embeddedness', Academy of Management Journal, 54, pp. 1069-1080.

Zaheer, A. and G. G. Bell (2005). 'Benefiting from network position: firm capabilities, structural holes, and performance', Strategic Management Journal, 26, pp. 809-825.

Zaheer, A., R. Gözübüyük and H. Milanov (2010). 'It's the connections: the network perspective in interorganizational research', Academy of Management Perspectives, 24, pp. 62-77.

Zhang, J., C. Baden-Fuller and V. Mangematin (2007). 'Technological knowledge base, R\&D organization structure and alliance formation: evidence from biopharmaceutical industry', Research Policy, 36, pp. 515-528.

Zheng, S. X. and D. A. Stangeland (2007). 'IPO underpricing, firm quality, and analyst forecasts', Financial Management, 36, pp. 1-20.

Zimmerman, M. A. (2008). 'The influence of top management team heterogeneity on the capital raised through an initial public offering', Entrepreneurship Theory and Practice, 32, pp. 391411 .

Erica Mazzola is a post-doctoral research fellow at University of Palermo. She received her PhD from the same university. Her main research interest focuses on open innovation and innovation management. In addition, her interests include research on strategic alliances and inter-firm networking strategies.

Giovanni Perrone is Professor of Business and Management Engineering at the University of Palermo, where he also chairs the DICGIM Department. His scientific activity focuses on operations and innovation management and, in particular, open innovation, inter-firm relationships and knowledge supply chains. He is co-author of 140 publications mainly within international journals and conference acts. $\mathrm{He}$ is a member of the board of editors and a reviewer for several international journals.

Dzidziso Samuel Kamuriwo is Senior Lecturer in Strategy at Cass Business School, City University London. He received his PhD from Cass Business School, City University London. His research interests include innovation strategy, venture capital and corporate governance 